\title{
STUDI KASUS PERAN PUSTAKAWAN DALAM PENERAPAN OPEN ACCESS DI PERPUSTAKAAN UIN MALANG
}

\author{
Dian Novita Fitriani \\ Mahasiswa Program Magister Ilmu Perpustakaan, Universitas Indonesia \\ E-mail: dian.novita.f@gmail.com
}

\begin{abstract}
Abstrak
The development of Open Access (OA) in Indonesia, especially in the academic library shows a fairly slow development. Obstacles to the development of OA are not technically, legally or economically, but more of a cultural constraint. UIN Malang Library is a university that develops both in Indonesia until now very concerned about OA. But in its development, development of OA in UIN Malang get obstacles, especially from the environment of academicians and leaders. By using Giddens' structural analysis, this research aims to see the role of librarian in developing OA in UIN Malang. This study uses a critical paradigm with qualitative research methods and case study approaches. From the results of the research found that librarian UIN Malang as an agent able to do the agency to the current structure. By holding the principles of $O A$, librarians make various efforts to provide understanding to the campus management and academic community to understand the "spirit" of OA as an alternative to scientific communication that has a significant role in the process of scientific communication especially within the scope of universities.
\end{abstract}

Keywords: Librarian, Open Access, Institutional Repository

\section{PENDAHULUAN}

Internet dan teknologi digital memiliki dampak yang cukup kuat terhadap komunikasi ilmiah. Dengan lahirnya internet dan teknologi digital, konten ilmiah banyak lahir dalam bentuk digital yang kemudian disusun, diproses, diproduksi dan disebarluaskan dalam bentuk digital. Perkembangan dipahami oleh komunitas ilmuwan sebagai sebuah potensi untuk model penerbitan ilmiah yang awalnya tradisional menjadi sebuah model baru tanpa hambatan, dengan kata lain dapat membuka akses bagi kaum ilmuwan. (Johnson, 2014)

Berkembangnya internet dan teknologi digital juga telah menciptakan banyak revolusi. Salah satu revolusi dalam bidang perpustakaan dengan perannya dalam komunikasi ilmiah adalah berkembangnya Open Acces atau disingkat menjadi OA. OA muncul seiring dengan munculnya internet di akhir tahun 1960-an dan berkembangnya web pada pertengahan tahun 1990-an (Priyanto, 2015). Literatur 
dalam OA bersifat digital, online, gratis biaya dan bebas dari pembatasan hak cipta dan perizinan.

Harnad dan Brody dalam Johnson (2014) secara ringkas menggambarkan manfaat OA secara dramatis dapat meningkatkan jumlah pengguna potensial dari setiap artikel. Adanya OA juga dapat menambahkan pengguna yang seharusnya tidak dapat mengakses literatur yang disediakan oleh suatu institusi tertentu. Sedangkan menurut Wiilinsky dan Alperin dalam Johnson (2014) mengemukakan bahwa berkembangnya OA juga menimbulkan masalah etika ekademis yang berkaitan dengan pengakuan dari masyarakat.

Gerakan OA di Indonesia masih terlihat berkembang dengan perlahan. Pada tahun 2015, hanya terdapat 33 perpustakaan akademis yang mendaftarkan repositori mereka ke OpenDOAR, sebuah direktori repositori akses internasional. Jika dibandingkan dengan jumlah perguruan tinggi di Indonesia, angka tersebut masih terhitung kecil. Ada banyak seminar, diskusi, dan publikasi yang membahas tentang OA namun belum ada tindak lanjutnya. Meskipun internet sudah berkembang di Indonesia, banyak perpustakaan akademi yang membatasi akses repositorinya dan bahkan tidak dapat diakses melalui web. (Priyanto, 2015)

Hasil penelitian diatas diperkuat oleh penelitian yang dilakukan oleh Liauw, T dan Genoni, P. (2017). Penelitian tersebut melakukan analisis terhadap 52 situs repositori kelembagaan pendidikan tinggi di Indonesia antara bulan November 2014 dan Februari 2015. Dari hasil penelitian tersebut dihasilkan bahwa 26,9\% Institutional Repository (IR) yang disurvei menyediakan semua atau sebagian besar dokumen secara lengkap. Pengembangan IR di Indonesia memiliki motivasi dalam pengelolaan informasi institusi, prestise institusi dan kebutuhan untuk memerangi plagarisme.

Penelitian yang dilakukan oleh Priyanto (2015) tentang kesiapan pustakawan akademik dalam implementasi Open Access Repository (OAR) menunjukkan bahwa pustakawan akademik di Indonesia masih kurang akrab dengan OA da OAR. Pemahaman pustakawan tentang OA masih terbatas pada sifatnya secara teknis. Pustakawan sudah memahami manfaat OA dalam komunikasi ilmiah dan siap 
mengimplementasikan OAR. Namun sebagaian besar pustakawan mengimplementasikan OA didasarkan pada tujuan untuk mencapai peringkat tertentu dalam rangking universitas kelas dunia dan webometrics. Penerapan OA yang dilakukan oleh pustakawan masih mengalami keterbatasan dari segi infrastruktur, ketrampilan, dan pengetahuan OA.

Dari beberapa hasil penelitian diatas dapat ditarik kesimpulan bahwa penerapan OA di Indonesia, khususnya pada perpustakaan akademik masih belum optimal. Jumlah perguruan tinggi yang telah menerapkan OA masih terhitung kecil jika dibandingkan dengan jumlah perguruan tinggi yang ada. Selain itu, Tjiek (2009) mengungkapkan bahwa perpustakaan perguruan tinggi pada umumnya memberlakukan berbagai peraturan yang harus dipenuhi oleh pengguna dalam mengaksesnya. Hal ini didasarkan oleh permintaan jurusan-jurusan untuk membatasi akses penggunaan koleksi. Batasan akses penggunaan ke koleksi biasanya berupa perlunya surat ijin untuk menggandakan. Selain itu juga terdapat batasan urutan, jenis dan jumlah halaman yang boleh digandakan. Berbagai batasan tersebut tentu bertolak belakang dengan semangat dari profesi kepustakawanan yang memiliki misi untuk mendiseminasikan informasi secara luas.

Beberapa alasan atau pendapat umum yang mendasari pembatasan akses penggunaan koleksi tesis/ disertasi. Pertama, terkait plagiarism. OA terhadap koleksi tesis/disertasi dapat dikhawatirkan atau bahkan dapat diyakini akan menyuburkan praktik plagiarism. Kedua, terkait tentang kualitas tesis/disertasi. Pendidikan tinggi di Indonesia masih mempertanyakan kualitas dari karya tulis yang dihasilkan. Sehingga jika memberlakukan OA, perguruan tinggi tersebut akan menanggung malu jika karya tulis ilmiah yang kurang baik kualitasnya tersebut diketahui oleh masyarakat umum (Tjiek, 2009).

Dari berbagai uraian diatas, dapat disimpulkan bahwa pada dasarnya kendala dalam pengembangan OA bukan dikarenakan kendala secara teknis, namun lebih kepada kendala budaya. Hal ini juga diungkapkan oleh Suber (2012) jumlah institusi yang menyediakan OA telah tumbuh dengan pesat selama lebih dari satu dekade. Namun pengembangannya cukup rumit, karena pada dasarnya kendala utama dalam 
pengembangan OA bukan secara teknis, legal maupun ekonomi, namun lebih kendala secara budaya.

Permasalahan terkait pembatasan akses pada OA juga dialami oleh Perpustakaan UIN Malang. Perpustakaan UIN Malang adalah perpustakaan akademik di sebuah perguruan tinggi negeri di Indonesia. Perpustakaan UIN Malang telah mengembangkan OA sejak tahun 2010. Namun setelah satu tahun berjalan, pengembangan OA sempat diberhentikan oleh pihak manajemen perguruan tinggi. Hal ini dikarenakan pengembangan OA di perpustakaan UIN Malang sempat mendapatkan resistensi dari para dosen. Para dosen saat itu menyampaikan keberatannya langsung kepada rektor, tanpa mengkomunikasikan ke pihak perpustakaan. Namun seiring berjalannya waktu, OA di UIN Malang berkembang cukup baik hingga saat ini. Dengan memfokuskan diri sebagai repository untuk kepentingan ilmiah, perpustakaan UIN Malang membranding repositorynya dengan sebutan "Research Repository".

Giddens dengan teori strukturasinya menjelaskan tentang struktur dan agen. Bagi Giddens, agensi merujuk pada kapasitas bertindak yang mengimplikasikan sebagai kekuasaan. Kekuasaan dalam hal ini dipahami sebagai kapasitas transformatof dimana menjelaskan tindakan manusia secara rutin yang mampu mereproduksi struktur. Sedangkan struktur mengacu pada perangkat aturan dan sumber daya yang bergerak dan digunakan oleh agen untuk bertindak.

Dalam penelitian ini, struktur yang dimaksudkan adalah manajemen UIN Malang dengan seperangkat peraturan dan sumber dayanya dan sivitas akademika UIN Malang. Sedangkan agen yang dimaksudkan adalah para pustakawan yang mengembangkan OA. Berbagai upaya yang dilakukan oleh pustakawan dalam mengembangkan OA di UIN Malang meskipun sebuah agensi yang dilakukan oleh agen untuk mengubah struktur yang ada dengan tindakannya secara rutin. Dari permasalahan ini, peneliti tertarik untuk melihat; bagaimana pandangan pustakawan terhadap Open Access di Perpustakaan UIN Malang? dan bagaimana tindakan yang dilakukan oleh pustakawan terhadap kebijakan Open Access di Perpustakaan UIN Malang? 


\section{METODELOGI PENELITIAN}

Paradigma dalam penelitian ini adalah paradigma kritis yang memiliki tujuan membuka, memindahkan, dan atau membuang keyakinan dan ide keliru tentang masyarakat dan realitas sosial. Paradigma kritis banyak digunakan dalam kajiankajian yang mampu mempelajari distribusi kekuatan yang tidak seimbang (menguntungkan sebagian dan merugikan pihak lain. Paradigma kritis ini berusaha untuk menghasilkan transformasi dalam tatanan sosial, menghasilkan pengetahuan yang bersifat historis dan struktural yang dinilai berdasarkan tingkat historis dan kemampuan menghasilkan praksis atau tindakan. (Lincoln, 1998)

Penelitian ini menggunakan metode penelitian kualitatif dengan pendekatan penelitian studi kasus. Penelitian kualitatif digunakan dalam studi untuk mengeksplorasi dan memahami makna pada sejumlah individu atau sekelompok orang yang dianggap berasala dari masalah sosial atau kemanusiaan. (Creswell, 2007, 2010) Sedangkan pendekatan penelitian studi kasus digunakan untuk menyelidiki secara cermat suatu program, peristiwa, aktivitas, proses, atau sekelompok individu

yang dibatasi oleh waktu dan aktivitas dan peneliti mengumpulkan berbagai data berdasarkan waktu yang telah ditentukan (Stake, 1995 dalam Creswell, 2010)

Teknik penentuan informan yang digunakan dalam penelitian ini adalah purposive sampling. Purposive Sampling yaitu pemilihan informan berdasarkan pada kriteria tertentu yang ditentukan oleh peneliti agar didapati informan yang sesuai untuk penelitian. Purposive Sampling yaitu pemilihan informan berdasarkan pada kriteria tertentu yang ditentukan oleh peneliti agar didapati informan yang cocok untuk penelitian. Kriteria yang dipilih pada penelitian ini adalah: 1) Pustakawan, 2) Lama bekerja di perpustakaan UIN Malang kurang lebih 7 tahun, 3) Ikut dalam pengembangan OA di perpustakaan UIN Malang. Dalam penelitian ini, jumlah informan yang didapatkan adalah 3 orang yaitu, AA, BB dan CC.

\section{PEMBAHASAN}

Pengembangan OA di perpustakaan UIN Malang telah dimulai sejak tahun 2011, satu tahun setelah perpustakaan UIN Malang mulai mengembangkan IR di 
perpustakaan. Dalam pengembangan OA, perpustakaan UIN Malang memiliki 3 situs yang memiliki peruntukkan masing-masing. Pertama, open access institutional repository (OAIR) yang berisi karya-karya dari dosen. Kedua, etheses yang berisi karya-karya dari mahasiswa. OAIR dan theses merupaka bentuk green open access. Green open acces merupakan salah satu saluran informasi berbasis open access dimana penulis atau peneliti menyerahkan tulisan atau hasil penelitian ke institusional repository. Sedangkan yang ketiga adalah e-journal atau biasa disebut dengan OA journal yang berisi karya-karya berupa jurnal yang diterbitkan pada lingkungan institusi perguruan tinggi. OA journal merupakan salah satu bentuk saluran informasi bebarbasis open access dimana peneliti atau penulis menyerahkan karyanya kepada penerbit yang mengadopsi sistem open access yang disebut dengan golden open acces.

Pihak manajemen yang cukup aware dengan perkembangan memberikan izin kepada Perpustakaan untuk mengembangkan OAIR. Untuk mendukung hal tersebut, pihak manajemen juga membuatkan payung hukum atau SK dalam pengembangan OAIR di UIN Malang. Seiring dengan perkembangannya, OA di perpustakaan UIN Malang tidak serta merta mendapatkan dukungan secara penuh oleh pihak manajemen perguruan tinggi maupun sivitas akademika. Pada tahun 2010, perpustakaan UIN Malang masih terbatas mengembangkan IR yang close access. Hal ini dikarenakan pengembangan OA masih belum banyak dilakukan oleh perguruan tinggi di Indonesia. UIN Malang merupakan perguruan tinggi kedua yang mulai menerapkan OA.

Pada tahun 2011, IR perpustakaan UIN Malang mulai mendapatkan izin untuk melakukan OA. Namun setelah satu tahun dibukanya OA, seiring dengan pergantian rektor waktu itu, beberapa dosen menolak dan melaporkan keberatan tersebut kepada pihak manajemen perguruan tinggi. Sehingga OA di UIN Malang terpaksa harus diberhentikan sementara waktu.

Penutupan akses pada repository oleh pihak manajemen perguruan tinggi, tidak menyurutkan semangat pustakawan di peprustakaan UIN Malang dalam megembangkan OA. Tim manajemen perguruan tinggi dalam pandangan Giddens 
merupakan sebuah struktur yang memiliki "rules and resources" atau tata aturan dan sumber daya yang selalu diproduksi dan direproduksi. Tim manajemen memiliki tata aturan yang harus dijalankan oleh para agen didalamnya. Namun para agen melalui agensi memiliki hubungan dualitas yang dapat melahirkan tindakan sosial tertentu. Hubungan dialektis antar agen dengan struktur inilah disebut oleh Giddens sebagai strukturasi.

Menurut Barker (2011 dalam (Demartoto, 2013) strukturasi mengandung tiga dimensi, yaitu ; Pertama, pemahaman yaitu cara agen dalam memahami sesuatu. Kedua, moralitas atau arahan yang tepat, menyatakan cara yang seharusnya dilakukan oleh agen. Ketiga, kekuasaan dalam bertindak, menyatakan cara agen dalam mencapai suatu tujuan tertentu. Dalam penelitian ini pustakawan adalah agen yan saling berintegrasi yaitu melakukan hubungan timbal balik dengan struktur yang dapat memproduksi beberapa temuan yaitu pandangan dan pemahaman mengenai OA dan tindaan yang dilakukan dalam mengembangkan OA.

\section{Pandangan Pustakawan terhadap OA}

Dalam strukturasi Giddens, dimensi pertama dalam strukturasi adalah pemahaman, yaitu bagaimana agen dalam memahami sesuatu. Dalam penelitian ini, agen yang dimaksudkan adalah pustakawan. Pemahaman pustakawan terhadap OA perlu dipahami sebagai awal sebelum melakukan berbagai tindakan dalam mengembangkan OA. Giddens mengungkapkan bahwa agen sebagai individu memiliki alasan-alasan untuk melakukan tindakan dan kemudian mengelaborasi alasan-alasan ini secara terus menerus atau berulang.

Pemahaman pustakawan terhadap pengembangan OA dapat dilihat dari ketiga sumber dalam mengungkapkan tentang OA. Menurut CC, perpustakaan memiliki peran yang sangat penting dalam publisher tesis misalnya pengembangan IR. Kemudian melatih akademisi terkait academic writing, reference, model bisnis, penerbitan, copyright, dsb. Namun sayangnya pustakawan di Indonesia belum banyak yang menguasai kemampuan tersebut. Hal ini juga dijelaskan oleh AA bahwa tidak banyak baik dari praktisi maupun akademisi dalam bidang perpustakaan. Dari segi akademisi juga tidak banyak yang mengambil komunikasi ilmiah sebagai topik 
penelitiaan. Dan sayangnya, dalam pendidikan ilmu perpustakaan belum ada mata kuliah yang secara khusus membahas hal tersebut.

AA mengungkapkan bahwa berbagai fenomena yang terjadi saat ini harusnya menjadi refleksi bagi pustakawan untuk memahami OA secara komprehensif. Berbagai kemampuan khususnya dalam mengidentifikasi jurnal ilmiah perlu dimiliki oleh pustakawan yang kemudian disosialisasikan kepada pengguna. Dalam hal ini, pustakawan perguruan tinggi dan puskawan di perpustakaan penelitian perlu melakukan evaluasi terhadap berbagai agregator jurnal ilmiah. Dari hasil survey secara sederhana yang dilakukan oleh AA, beberapa agregator jurnal itu sebagian besar artikel ilmiahnya didapatkan dari OA. Survey tersebut dilakukan dengan melihat prosentase jurnal yang OA, diembargo dan diskontinyu. Pustakawan harus "literate" terhadap berbagai sumber ilmiah yang ada. Pustakawan harus menguasai landscape publikasi ilmiah secara global dan memahamkan hal tersebut kepada pengguna.

Sebagai seorang pustakawan, AA mengungkapkan pentingnya memahami ruh dan prinsip dari OA secara tepat. Pemahaman ini juga perlu diberikan kepada pimpinan perguruan tinggi. Setidaknya pustakawan harus memahami definis operasional dari OA. Beberapa unsur dalam definisi operasional OA yang perlu diperhatkan; tersedianya file dalam full text, harus segera dipublikasikan secara online dengan tidak menunggu 1 atau 2 tahun kemudian. Bahkan jika pengguna mendownload dan harus melakukan register dan lain sebagainya, hal tersebut merupakan salah satu technical barrier dalam OA.

AA memahami bahwa OAIR adalah saluran komunikasi ilmiah alternatif. Sehingga praktik-praktik OA yang masih belum maksimal dengan membatasi akses pada OA dianggap bukan lagi menjadi sebuah alternatif. Selain itu, OAIR harus benar-benar ilmiah dimana didalamnya memuat konten-konten yang benar-benar ilmiah. Sayangnya, di beberapa perguruan tinggi OAIR memuat konten-konten tidak ilmiah seperi kliping koran dan konten non ilmiah lainnya.

Pemahaman tentang repository tersebut melatar belakangi tindakan yang dilakukan oleh pustakawan dengan memberikan nama pada OAIRnya dengan nama 
"Research Repository". Selain sebagai branding OAIR dari UIN Malang untuk menegaskan konten didalamnya hanya yang bersifat ilmiah, pustakawan juga ingin memahamkan kepada dosen-dosen bahwa tulisan yang diperbolehkan dimuat dalam OAIR adalah tulisan ilmiah.

Agen menurut Giddens memiliki aspek inheren terhadap apa yang mereka pahami dan apa yang akan mereka lakukan. Setiap manusia merupakan agen yang bertujuan (purposive agen), karena setiap individu memiliki alasan untuk tindakantindakannya yang kemudian mengelaborasi alasan-alasan tersebut secara terus menerus dan berulang-ulang. Individu melakukan tindakan yang bertujuan, bermaksud dan bermotif.

\section{Tindakan Pustakawan dalam Mengembangkan OA di Perpustakaan UIN Malang}

Giddens membedakan kesadaran menjadi kesadaran diskursif dan kesadaran praktis. Kesadaran diskursif merupakan kesadaran yang dilakukan dengan melukiskan tindakan dalam kata-kata. Sedangkan kesadaran praktis merupakan kesadaran yang diwujudkan dalam bentuk tindakan yang dianggap benar oleh agen tanpa mengungkapkan kata-kata tentang apa yang mereka lakukan (Giddens, 2011). Kesadaran diskursif dan kesadaran praktis tidak terdapat batasan, namun terdapat perbedaan-perbedaan antara apa yang dapat dikatakan dengan apa yang dapat dilakukan. Kesadaran praktis ini menjadi dasar dari teori strukturasi Giddens. Giddensd secara konsisten melihat struktur dalam kehidupan masyarakat sebagai sesuatu yang tidak lepas dari tindakan manusia yang berada didalamnya, begitu pula sebaliknya.

OA di UIN Malang mulai berjalan sejak tahun 2010. Gagasan tentang OA ini awalnya dimulai dengan dibangunnya repository yang masih menggunakan akses tertutup. Saat itu, pustakawan secara pelan-pelan mengkomunikasikan ide pengembangan OA di lingkungan UIN Malang untuk pengembangan ilmu pengetahuan. Menurut CC, pada tahun tersebut pengembangan OA masih belum umum dilakukan oleh perguruan tinggi di Indonesia. Hal ini juga diperkuat oleh AA 
yang mengatakan bahwa perpustakaan UIN Malang menjadi perpustakaan kedua dalam mengembangkan OA di Indonesia setelah perpustakaan UK Petra.

Dalam mengajukan ide-ide untuk mengembangkan OA, pustakawan menjelaskan berbagai tujuan. Salah satu tujuan idealnya adalah untuk pengembangan ilmu pengetahuan. Selain tujuan secara ideal, pustakawan juga menjelaskan secara pragmatis terkait perankingan dalam webometrik. Hal ini dijelaskan juga oleh AA bahwa OA dapat didekati dari berbagai aspek, dari pendekatan secara ideal hingga pendekatan pragmatis. Dalam hal ini, AA memberikan contoh terkait kenaikan pangkat dan jabatan dosen yang dituntut untuk mengupload karyanya dalam bentuk online. Hal tersebut merupakan sebuah tujuaan pragmatis yang perlu diungkapkan juga oleh pustakawan.

Ide pengembangan OA dari perpustakaan UIN mendapatkan dukungan penuh oleh pihak manajemen kampus. Pihak manajemen kampus mengeluarkan payung hukum terkait pengembangan OA di UIN Malang. Payung hukum tersebut secara resmi dikeluarkan oleh rektor dalam bentuk Surat Keputusan. Dalam pandangan Giddens struktur itu sebagai tata aturan dan sumber daya yang selalu diproduksi dan direproduksi, serta memiliki dualitas dengan agensi, serta melahirkan berbagai praktik sosial sebagaimana tindakan sosial. Dalam penelitian ini, peraturan yang dikeluarkan oleh pihak manajemen kampus menunjukkan sebuah struktur. Dimana struktur adalah aturan dan sumber daya atau seperangkat relasi transformasi, terorganisasi sebagai kelengkapan-kelengkapan dari sistem-sistem sosial (Nashir, 2012).

Giddens mengungkapkan bahwa struktur sebagai aturan dan sumber daya yang selalu diproduksi dan direproduksi. Dalam hal ini, agen menggunakan aturanaturan untuk memperkuat tindakannya. Penetapan payung hukum untuk pengembangan OA tidak dapat dipandang secara statis. Artinya, payung hukum sebagai peraturan dapat berubah melalui praktik sosial. Pada tahun 2011, OA di UIN Malang terpaksa harus diberhentikan sesuai dengan perintah dari manajemen kampus. Hal ini dikarenakan pergantian dari rektor waktu itu yang memiliki perbedaan pemikiran terhadap pengembangan akses. Selain itu, hal tersebut juga dipicu oleh 
resistensi yang diberikan oleh beberapa dosen dari berbagai jurusan. Saat itu, dosen tidak menyetujui dengan pengembangan OA yang dilakukan oleh pihak perpustakaan. Menurut CC, beberapa alasan dari pihak dosen dalam pengembangan OA adalah kekhawatiran terhdapa plagiarisme dan kurang percaya dirinya dosen terhadap karya dari mahasiswa-mahasiswanya. Dalam tulisan Tjiek (2009) juga diungkapkan bahwa sebagaian besar alasan yang menjadi hambatan OA adalah tentang plagiarisme dan kualitas kerya ilmiah yang akan dipublikasikan.

Pustakawan sebagai agen memiliki kekuasaan untuk melakukan tindakan. Kapasitas dalam bertindak ini mengimplikasikan kekuasaan. Tindakan yang dilakukan oleh pustakawan tercermin dalam interaksi sosial. Dalam penelitian ini, pustakawan menjalankan kekuasaannya melalui proses interaksi dengan pihak manajemen kampus. Pustakawan mencoba memahamkan kepada pihak manajemen kampus terkait berbagai dampak yang dapat timbul jika OA ditutup. Penutupan OA oleh pihak manajemen kampus juga menjadi menjadi bahan evaluasi bagi pihak pustakawan. Pustakawan menyadari bahwa pendekatan yang dilakukan sebelumnya dengan cara top-down kurang tepat dilakukan. Dengan adanya resistensi dari pihak dosen, hal ini menunjukkan bahwa kurangnya pustakawan mengkomunikasikan ide pengembangan OA tersebut secara menyamping di tataran dosen dan mahasiswa.

Secara konkret, strukturasi Giddens dapat dipahami sebagai relasi antara agen dan struktur yang perwujudannya berupa praktik sosial (social practice) yang dapat dilihat dalam kehidupan masyarakat sehari-hari. Relasi antara agen dan struktur dapat dilihat dari berbagai pendekatan dilakukan oleh pustakawan untuk mendapatkan izin dari pihak manajemen kampus untuk membuka kembali OA. Pustakawan secara lebih masif melakukan kegiatan literasi untuk dosen dan memahamkan spirit OA yang diusung oleh pustakawan. Pemahaman tentang spirit OA kepada seluruh sivitas akademika ditujukan agar tidak hanya pustakawan dan perpustakaan yang dianggap paling paham dengan OA, namun OA mampu menjadi tanggung jawab bersama di kalangan sivitas akademika.

Sayangnya, pengembangan OA di Indonesia seringkali dikaitkan dengan perankingan dalam webometrics. Menurut AA, webometrik memang digunakan 
untuk mengukur komitmen perguruan tinggi dalam mendukung OA. Namun sayangnya praktik tersebut di Indonesia seringkali disalah artikan. Berbagai perguruan tinggi melakukan berbagai trik untuk menaikkan ranking webometrik melalui OA. Salah satu trik yang dilakukan dengan memecah file menjadi beberapa bagian dan akses yang dibuka hanya pada bab-bab tertentu.

Tuntutan untuk menaikkan ranking dalam webometrik juga terjadi di UIN Malang. Hal ini diungkapkan oleh AA bahwa terdapat tuntutan dari pihak manajemen untuk menaikkan ranking pada webometrik. Bagi Giddens, struktur mengacu kepada peraturan dan sumber daya yang bergerak dan digunakan oleh agen untuk bergerak. Dalam hal ini, tuntutan pihak manajemen untuk menaikkan ranking webometrik merupakan bentuk strukturasi yang berupa peraturan. Namun hal tersebut tidak berlangsung lama. Pustakawan melakukan berbagai upaya untuk memberikan pemahaman kepada pihak manajemen kampus dan sivitas akademika bahwa OA seharusnya menjadi tanggung jawab bersama, bukan hanya menjadi tanggung jawab perpustakaan. Hal ini menunjukkan bahwa struktur dapat digunakan oleh agen untuk bertindak. Selain itu, seperti yang diungkapkan oleh Giddens (dalam Lubis, 2016) bahwa struktur tidak hanya berfungsi sebagai pemaksa namun struktur memberi peluang bagi agen.

Berbagai upaya yang dilakukan oleh pustakawan untuk memberikan pemahaman tersebut, bertujuan untuk membentuk kebiasaan melakukan berbagi pengetahuan melalui OA. AA mengungkapkan bahwa saat ini jika terdapat pengumuman ranking webometric dan peringkat UIN Malang menurun, dosen-dosen secara langsung melakukan evaluasi terhadap dirinya sendiri untuk memperbanyak tulisannya di OAIR. Dengan contoh kasus tersebut menunjukkan bahwa dosen-dosen telah memahami prinsip dari OA yang dikembangkan oleh perpustakaan UIN Malang

\section{PENUTUP}

Teori Giddens tentang strukturasi memberikan paradigma baru bahwa tidak selalu strukturlah atau sebaliknya agenlah yang dominan dalam praktik sosial manusia atau masyarakat. Perwujudan kehidupan masyarakat dapat dilihat dalam 
berbagai praktik sosial yang merupakan relasi saling timbal-balik atau dualitas antara struktur dan agen dalam fakta sosial yang obyektif. Dalam penelitian ini, pihak manajemen kampus, sivitas akademika UIN Malang maupun pustakawan tidak mendominasi satu dengan lainnya. Pengembangan OA di UIN Malang dipandang sebagai sebuah relasi timbal balik antara pihak manajemen kampus, sivitas akademika UIN Malang khususnya dosen dan mahasiswa, serta pustakawan sebagai agen. Pustakawan sebagai agen melakukan agensi terhadap struktur yang diciptakan oleh pihak manajemen kampus maupun dari sivitas akademika UIN Malang. Agensi yang dilakukan dalam kesadaran praktis dengan berbagai tindakan untuk melakukan strukturasi terhadap struktur yang berjalan.

\section{DAFTAR PUSTAKA}

Charles W. Bailey, J. (2006, Juli 2). What Is Open Access? Retrieved Desember 7, 2017, from Digital Scholarship: http://digitalscholarship.org/cwb/WhatIsOA.pdf

Demartoto, A. (2013, Februari 5). Teori Strukturasi dari Anthony Giddens. Retrieved Desember 1, 2017, from http://argyo.staff.uns.ac.id/2013/02/05/teoristrukturasi-dari-anthony-giddens/

Giddens, A. (2011). Teori Strukturasi : Dasar-dasar Pembentukan Struktur Sosial Masyarakat.

Johnson, P. (2014). Fundamental of Collection Development and Management. Chicago: ALA.

Lincoln, N. K. (1998). The Landscape of Qualittative Research : Theories and Issues. California: Sage Publication.

Lubis, A. Y. (2016). Postmodernisme: Teori dan Metode. Jakarta: Raja Grafindo Persada.

Nashir, H. (2012). Memahami Strukturasi dalam Perspektif Sosiologi Giddens. Sosiologi Reflektif, Vol. 7 No. 1.

Priyanto, I. F. (2015). Readiness Of Indonesian Academic Libraries For Open Access And Open Access Repositories Implementation: A Study On Indonesian Open Access Repositories Registered In OpenDOAR. United States: University of North Texas.

Redaksi Majalah Filsafat Driyakarya. (2000). Menelusuri Gagasan Anthony Giddens. Majalah Filsafat Driyakarya, 2-4.

Suber, P. (2012). Open Access. United State: MIT Press.

Tjiek, L. T. (2009). Open Access: Menyuburkan Plagiarisme? Visi Pustaka, 19-22. 